International Journal of Instruction e-ISSN: 1308-1470 • www.e-iji.net

Article submission code: 20201025103912

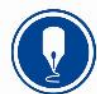

October $2021 \bullet$ Vol.14, No.4

p-ISSN: 1694-609X

pp. 659-678

Received: 25/10/2020

Revision: 13/04/2021
Accepted: 06/05/2021

OnlineFirst: 26/08/2021

\title{
Can Pupils Retell Concepts in English? An Analysis of How to Use EMI in Science Class
}

\section{Rendi Restiana Sukardi}

Science Education Program of Post Graduate School, Universitas Pendidikan Indonesia, Bandung, Indonesia, rendisukardi@upi.edu

\section{Wahyu Sopandi}

Prof., Chemistry Education Department, Universitas Pendidikan Indonesia, Bandung, Indonesia,wsopandi@upi.edu

\section{Riandi}

Assoc. Prof., Biology Education Department, Universitas Pendidikan Indonesia, Bandung, Indonesia, rian@upi.edu

British Council for East Asia reported that the level of English competency of Indonesian pupils in primary and secondary education in English lessons and other scientific disciplines was very concerning. They did not use English as Medium Instruction (EMI) in Science class well. Besides, pupils need to have English communication skills in the 21st century. Because of that, the research aims to investigate how EMI should be applied in Science class. The purposive survey method was used in this study involving the process of data triangulation from tests, questionnaires, unstructured interviews, and observations of learning. The research subjects were selected by a purposive sampling technique involving 172 pupils aged 11-13 years from several secondary schools in four major cities in Indonesia which use English as the medium of instruction in Science class. The results showed that EMI can be applied in Science class by bilingual strategies. Most of the pupils understood the teachers' instruction, scientific terms, even scientific concepts but they felt safer using both Indonesian and monolingual languages to avoid some errors e.g. misconceptions when teachers explain fundamental science concepts. Introducing keywords in the form of bilingual terms related to the fundamental concepts of science helps pupils to understand science concepts more deeply and develop pupils' ability to speak English actively. These findings are expected to become a reference for how to use EMI in science class.

Keywords: EMI, science concept, bilingual, English lessons, science class

\section{INTRODUCTION}

Indonesian people's awareness of the urgency of the use of English in the education process has risen since the late 90 's, and this is still increasing because it provides a

Citation: Sukardi, R. R., Sopandi, W., \& Riandi. (2021). Can pupils retell concepts in English? An analysis of how to Use EMI in science class. International Journal of Instruction, 14(4), 659-678. https://doi.org/10.29333/iji.2021.14438a 
meaningful and positive contribution (Abduh \& Rosmaladewi, 2019; Hadisantosa, 2010; Lamb \& Coleman, 2008). The growth of awareness to build a scientific community among Indonesians with English as the medium of instruction is also one of the supporting factors or special considerations of teaching English from the early age because it might show the intelligence and social status (Abduh \& Rosmaladewi, 2019; Khasbani, 2019). English is taught from kindergarten to tertiary institutions in Indonesia. Even at the high school level, English is a compulsory subject tested in the National Examination. Therefore, since 2003, English has been adopted as a medium of instruction in Indonesia (Abduh \& Rosmaladewi, 2019; Margana, 2015). This marked the beginning of the use of EMI in the field of education, including science classes in Indonesia.

Policymakers in the Indonesian Ministry of National Education assume that English has a vital role in supporting and improving the quality of standardized national school graduates such as those in member countries of the Organization for Economic Cooperation and Development (Bax, 2010; Dearden, 2014; Khasbani, 2019; Lawson \& Sayers, 2017). The British Council for East Asia states that one of the goals of using English in Indonesian schools is to form a superior generation that is capable to compete in international forums in both natural and social sciences (Dearden, 2014). However, according to a report published by the British Council for East Asia in 2009, the level of English competency of Indonesian pupils in primary and secondary education in both in English lesson and other scientific disciplines was very concerning (Dearden, 2014; Hadisantosa, 2010; Kirkpatrick, 2012). Mukminin et al. (2018) also reported that the majority of elementary and secondary school pupils in Indonesia faced problems in following lessons using English as a medium of instruction so they tend to use memory strategy.

The problems faced by the pupils are due to their mother tongue and the position of English as a foreign language for them. It does not only involve linguistic matters but also larger issues such as national identity (Al Hosni, 2014; Dewi, 2017; Fitriati, 2015). Another reason is the fact that Indonesia is one of the expanding circle countries in the use of English (Jenkins, 2003; Kachru, 1992), where English is used for various purposes (including education) but does not make it the dominant language in daily communication. Unfortunately, the fact that the most recent sources of knowledge and technology are mostly published in English in very large portions is undeniable. Besides, bilingual practices in Science classes are on the rise because of the internalization of education (Archila \& de Mejía, 2017; Lauder, 2010; Rini, 2014). This is one of the reasons why English is used as a medium of instruction in teaching knowledge and technology, especially in science lessons. Most schools that offer science teaching with English as a medium for instructional learning generally adopt the content and language integrated learning approach (CLIL). This approach facilitates pupils to understand the content of the material while deepening their English grammar at the same time (Margana, 2015; Surdyanto, 2018). This strategy is certainly not easy to implement for non-native speakers of English, because learning science is not only in the form of instructional sentences but also the fundamental concepts of science in 
which coherence must be maintained to avoid misconceptions (Drubin \& Kellogg, 2012; Ünsal et al., 2018).

Although the use of English as a medium instruction has been implemented since the 1970 s, discussions and publications are found in limited numbers in Indonesia, so this field of research is relatively new in Indonesia (Mukminin et al., 2018). Research on science instruction in bilingual classes in the $21^{\text {st }}$ century is a potential research domain to be developed because of its urgency in preparing the young generation to face competition with OECD countries. Chu et al. (2017) mapped the relationship between the dimensions formulated by the OECD, the categories compiled by The Assessment and Teaching of 21st Century Skills (ATCS), and the expertise framework published by the Partnership for 21st Century Skills (P21). Based on the results of the framework study, it is revealed that communication skills are things that must be possessed by pupils where English is a supporting language, especially in learning science. Even one school in Japan labelled as Super Global School (SGS) incorporated in the UNESCO Associated Schools Project Network (ASPnet) explicitly states that pupils must have high communication skills in foreign languages, including English (Fredriksson et al., 2020).

Recognizing the vital position of both communication skill and English mastery in the development of Indonesia's human resources (HR) in the $21^{\text {st }}$ century, especially in the OECD countries community, the use of English as a medium of instruction in science teaching needs to be implemented. It needs the right formulation to build pupils' conceptual understanding and communication skills (Werther et al., 2014). However, not many studies in Indonesia have investigated the use of English as a medium of instruction in science classes. They only reported that results e.g. Indonesian pupils' English mastery was low. The suggestions seem bias and global. Therefore, research on pupils' ability to understand the instructions and basic concepts of science delivered by teachers in English needs to be examined specifically as a basis for consideration to develop appropriate science teaching programs in the future. Therefore, the findings of the research are expected to be a guideline for teachers on how to conduct Science class with EMI. The focus of this research is to investigate the formulation or implementation patterns of science instruction with EMI which are appropriate.

\section{Science Class and English as Medium of Instruction}

The language used as a teaching medium has a very vital role because it is one of the determinants of achieving the learning objectives (Martin, 2003; Saeed \& Jarwar, 2012). The use of EMI in science classes in Indonesia is a big gamble because English has become a lingua franca in various strategic sectors including in the development and publication of the latest science and technology and teaching in schools (Kirkpatrick, 2012; Lauder, 2010; Rini, 2014). Meanwhile, science as a scientific discipline has unique characteristics including scientific terms that can only be understood by people with a scientific background. It concerns the formation of a misconception if science is taught in a foreign language (Arkoudis, 2003; Ünsal et al., 2018). Moreover, the data shows that the English proficiency of elementary and middle school pupils in Indonesia is in an apprehensive category (Dearden, 2014; Hadisantosa, 2010). The things that 
teachers need to watch out for when teaching science with EMI is the depth of understanding and mastery of pupil concepts. The teacher must ensure that English is not a barrier for pupils in understanding the basic concepts of science. The researcher revealed that the use of foreign languages in a teaching that is poorly understood by pupils will hamper pupil learning progress but it will have great benefits if the use of the foreign language is formulated appropriately (Coleman, 2010; Coleman, 2016). The same thing was also mentioned by Lauder (2010) that the use of foreign languages must be appropriate and within the range of pupils' or pupils' understanding to minimize the barriers to learning. The use of two languages, i.e. English and mother tongue is an alternative in teaching science. This aims to minimize the confusion and inability of pupils to absorb and understand the basic scientific concepts so that communication becomes flexible but still meaningful. To maintain the meaningfulness of science learning, teachers can flexibly switch from English to their mother tongue if obstacles are found in communication as expressed by He \& Chiang (2016).

Difficulties related to the use of EMI in teaching various disciplines also at various levels of education occur in several countries that use English as a foreign language or a second language such as in Vietnam, South Korea, Ghana, and Uganda (Byun et al., 2011; Kyeyune, 2003; Owu-Ewie \& Eshun, 2015; Vu \& Burns, 2014). But this is not an obstacle because the use of foreign languages, especially English in teaching, can be adapted to various situations and conditions. Besides, teachers' efforts are needed in making alternative teaching strategies if the strategies implemented do not take place optimally with consideration of the selection of diction understood by pupils (Vithanapathirana \& Nettikumara, 2020). A bilingual teaching strategy can be an alternative teaching strategy because it allows teachers to control the basic misconceptions of science that is not understood by pupils.

The bilingual teaching strategy implemented must be designed with an effective formulation. However, the implementation of this bilingual teaching strategy requires synergy from pupils. As English is a foreign language, Indonesian pupils need to study English harder. Pupils must optimize the resources around them so that their understanding and mastery of the science concepts are optimal. Resources that can be optimized by pupils are English encyclopedias and digital English dictionaries (Hu \& Gao, 2020). The use of these resources is expected to be able to bridge the gap in the mastery of concepts and mastery of diverse English language skills of pupils. Moreover, based on the teacher's point of view, the adaptation of teaching models or methods and even curriculum is needed to meet the unique linguistic needs of pupils. This indicates that bilingual teaching strategies must also be flexible and not rigid (Marco-Bujosa et al., 2020). The vital thing that must be done by teachers is to introduce specific terms in the field of science because pupils who take a bilingual program tend to remember terms or vocabulary that are unique in the scientific field (Maxwell-Reid, 2020). The absolute thing that must be taken by the teacher is to formulate and design a special assessment by considering many aspects (Fine \& Furtak, 2020).

There is a tendency for an increase in the number of schools using English as EMI in their curriculum. Therefore EMI-related research is very potential to be developed, even 
though related research in Indonesia has started a long time ago (Mukminin et al., 2018). This is supported by the emergence of awareness in the Indonesian community that international relations both in the aspects of academics and career development require English (Lamb \& Coleman, 2008). A conventional view that has always been shared by teachers in Indonesia is that the use of EMI must consider the English language skills of teachers and pupils. This view is not wrong, but must be added to an understanding that what is also needed is the right formulation or strategy by considering the coherence of the fundamental concepts of science so that pupils' understanding is not only focused on linguistic aspects. The teacher is faced with a concern that pupils might fail to understand the fundamental concepts of science delivered in English because the teacher is not able to teach the concepts while helping pupils learn the language. However, through research involving the process of triangulation of data, a relatively unbiased conclusion can be obtained; for example, in this case is how the strategy teaches a scientific field with EMI. The results of this study are expected to contribute to the implementation of EMI in various subject matters.

\section{International Standard Schools (Sekolah Berstandar Internasional-SBI)}

Teaching with EMI is very identical to international standard schools (Sekolah Berstandar Internasional - hence SBI) which began to be popular in early 2003. This program facilitates pupils to develop themselves optimally, intellectually, emotionally, and spiritually. Besides, pupils are also equipped with relevant skills to develop a career in the future so they can compete globally. Although the $S B I$ era is over, the principle of developing teaching programs with EMI has not lost its purpose. Pupils with good English skills are expected to be able to compete competitively not only in regional scope, but also globally, as in OECD countries (Organization for Economic Cooperation Development). In the P21 framework (Partnership for 21st Century Skills) and the OECD framework, pupils must have learning and innovation skills, digital literacy skills or use information, media and technology access skills, and life skills in career development. If the conclusion is drawn from the two frameworks, communicating science and understanding various information requires a widely used language, i.e. English. In the end, pupils can socialize in the wide world of relationships in the career development arrangement by paying attention to language and cultural norms. This further reinforces the vital role of English as an important instructional medium in teaching. Some schools in Japan that are members of the UNESCO Associated Schools Project Network (ASPnet) explicitly state that English as a foreign language is one of the targets of pupil communication (Fredriksson et al., 2020).

\section{METHOD}

The research applied the purposive survey method to investigate how EMI should be implemented in Science classes. The method was chosen because the research applied the purposive sampling technique (Fraenkel et al., 2011). The research does not provide special treatment but only captures a phenomenon, analyses it, then concludes. Research data were collected through tests, questionnaires, unstructured interviews, and observations. They were processed quantitatively and qualitatively. 


\section{Participants}

This study involved 172 pupils from urban areas in Indonesia whose ages range from 11-13 years old. Indonesian is their native language while English is their foreign language. The descriptive data are presented in Table 1 . Five native Indonesian secondary science teachers were also involved as sample research. They are certified teachers in a private school with good English skills. The research subjects were selected using a purposive sampling technique by selecting pupils from schools that use English as a medium of instruction in a science lesson because the research has a specific purposive. This purposive sampling is identical to criterion-based selection (Roulston, 2010), which is choosing samples that are selected to provide important information that might not be obtained through other sampling techniques (Fraenkel et al., 2011). All pupils involved in this study were pupils who spoke Indonesian as the first language and met the criteria for good English language skills.

Table 1

Sample of research

\begin{tabular}{lllll}
\hline Characteristic & Category & $\mathrm{N}$ & $\%$ & SD \\
\hline Area & Bandung & 100 & 58.13 & 18.86796 \\
\cline { 1 - 4 } & Palembang & 20 & 11.63 & \\
\hline & Central Jakarta & 20 & 11.63 & 18.38478 \\
\hline Gender & Bekasi & 32 & 18.60 & \\
\hline & Male & 99 & 57.55 & 42.44 \\
\hline
\end{tabular}

Instruments and Procedure

There were two kinds of instruments. The first was a conceptual test that was analysed quantitatively. They were five essay questions. The second were instruments that were analysed qualitatively such as questionnaires containing eleven questions, unstructured interview questions, and an observation sheet. Unstructured interviews and observations were conducted to obtain clearer information. They were carried out to gain information on how were teacher-pupil interactions as well as the interaction between pupils. Unstructured interviews were used to gain unclear data from questionnaires. While observation was conducted to see teachers and pupils' habit in speaking English. We wanted to ensure and guarantee that they spoke English inside and outside the Science class. These assessments were qualitative and judgmental to produce logical validity (Taherdoost, 2016; Nassaji, 2015). We should use many instruments to gain qualitative data. The instrument blueprint is shown in Table 2.

Table 2

Instrument blueprint

\begin{tabular}{lll}
\hline Data & Indicator(s) & Items \\
\hline Conceptual Test & Describing enzymatic digestive & 2 \\
\hline & Describing absorption process in the intestine & 1 \\
\hline & Describing diseases and drugs of the digestive system & 2 \\
\hline Questionnaires & Pupils' ability to understand scientific terms & 3 \\
\hline & Pupils' ability to understand teaching instructions & 2 \\
\hline & Pupils' ability to understand the concepts of science and to paraphrase them & 5 \\
\hline & Pupils' opinion on the sustainability of EMI & 1 \\
\hline
\end{tabular}




\section{Data Analysis}

The research was conducted in 3 provinces, which consisted of 4 cities, i.e. West Java (Bandung and Bekasi), SCR of Jakarta (Central Jakarta), and South Sumatra (Palembang). There were two kinds of data i.e. qualitative and quantitative data. Those data were analysed to produce a conclusion on how EMI should be implemented in Science class. We are going to earn information on the suitable formulation of Science teaching with EMI as shown in Figure 1.

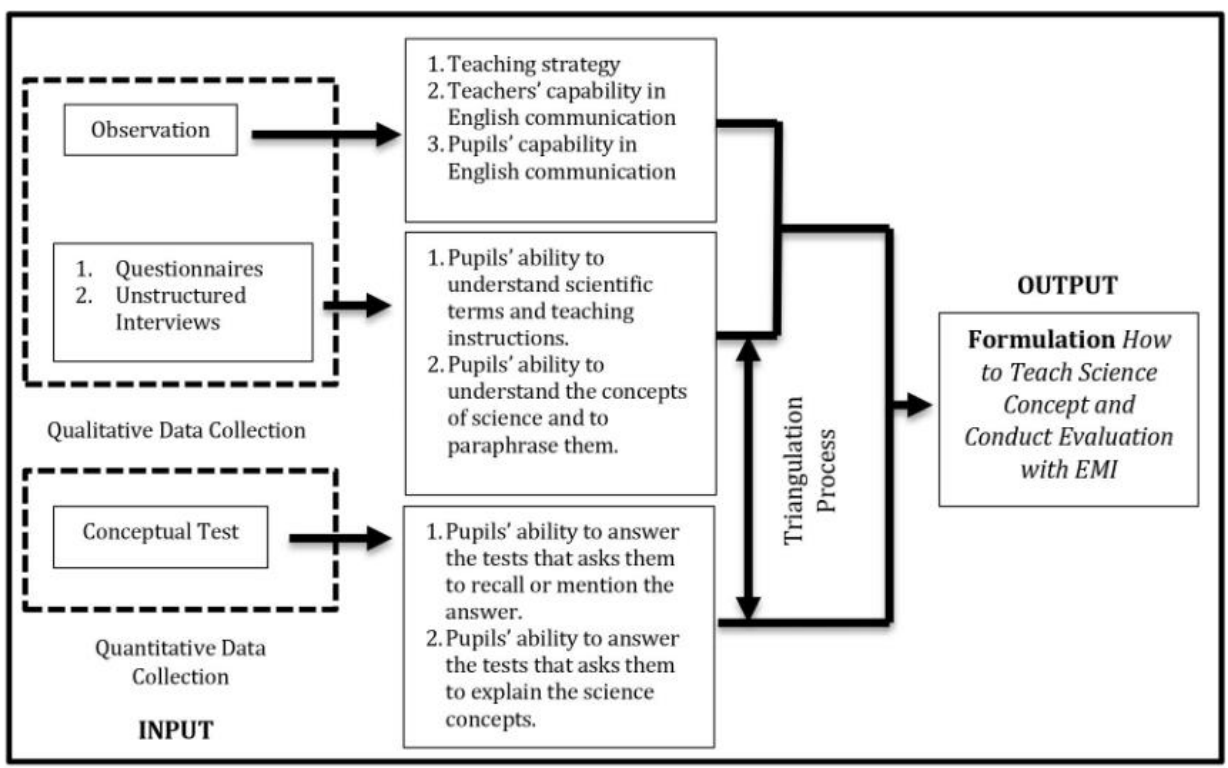

Figure 1

Data collection and analysis

The questions in the questionnaire collected main information i.e. the ability of secondary school pupils in Indonesia to understand teaching instructions, scientific terms, and the concepts of science delivered by teachers in English. The findings are then triangulated with the results of pupils' conceptual tests, observations, and unstructured interviews. Finally, the research can answer the question of how science teaching with EMI should be implemented and evaluated.

\section{Qualitative Data}

The first step was to carry out observations of classroom instruction to formulate questions that will be reconfirmed. Then the question was given to pupils in the form of a questionnaire. These questions were answered and then collected directly. To get clearer data, unstructured interviews and observations were conducted with pupils outside of class hours. The results of this interview were then simply coded to strengthen the data obtained previously. This encoding was related to the type of qualitative data (Linneberg \& Korsgaard, 2019). This coding was obtained from teacher and pupil 
interviews related to their participation in science learning using EMI. The data were then triangulated to obtain the information needed.

The data obtained through questionnaires were calculated in percentage to obtain information about pupils' ability to understand scientific terms, teacher's instructions, science concepts, and its paraphrases, as well as their opinions about the prospects for learning English in the science lessons e.g. Can you retell the science concept that was explained by the teacher? The data were then triangulated with data obtained from unstructured interviews with some pupil representatives.

\section{Quantitative Data}

The test was held at the end of the class. There were two kinds of questions in the test. The first was the questions that asked pupils to recall or to mentions the answers e.g. What is the name of the enzyme that works in the mouth? and Where does the absorption take place in our body? The second was a question that asked pupils to explain the answers, e.g. What would happen if the number of E. coli swells too much in the large intestine? and How do ulcer drugs work in our bodies? Both kinds of tests that contain different question types were tested in terms of their normality. Then we determined whether to use parametric or non-parametric statistics. The hypothesis was made, $\mathrm{H}_{0}$ means it is no difference between both test results and $\mathrm{H}_{\mathrm{a}}$ means there is a difference between both of test results. The data were analysed by using SPSS Ver.22 software.

\section{FINDINGS}

\section{Teachers' and Pupils' English Mastery}

The results of observations during the learning process in several classes indicate that neither pupils nor teachers have the habit of communicating in English actively. When the formal learning process is carried out in class, they can communicate in English well. However, when the teacher faces difficulties in explaining the science concept, the teacher unconsciously uses Indonesian. The same thing is shown by pupils, in less ideal conditions they used Indonesian when expressing the difficulties that they face in learning to get clearer explanations on science concepts.

During the break time, pupils gather in the canteen, sports field, and library. The results of the investigation show that they use Indonesian as a communication language. However, some of the questions raised in these informal conversations indicate that pupils have good communication skills in English, regardless of the accuracy of the grammar used. The English they use is understandable. Both pupils and teachers who teach in the science class receive intensive English tutoring. Observations on their recruitment documents also show that their English skills are not bad.

\section{Pupils' Understanding of Teachers' Instruction, Scientific Terms, and Scientific Concepts}

The analysis of pupil questionnaire answers shows that most pupils understand the scientific term delivered in the lesson. This is because the translation of the scientific 
term from English into Indonesian does not differ significantly, e.g. atom, calorie, convection, conductor, and frequency. This finding is reinforced by the results of pupil interviews where the term is very familiar to pupils. However, the pupils claim that they have difficulties in understanding the terms which have significant differences between translations in Indonesian and English, e.g. fluid, friction, pressure, and solubility. Meanwhile, what can be ascertained from the results of the interview is that pupils who do not like to read the textbooks automatically will have difficulty in understanding the scientific terms. This is an irony since pupils can easily get the latest information about science content in English both from textbooks and the internet.

Meanwhile, almost all pupils understand the instructions delivered by a teacher in English. The language used in teaching instruction is English which is often used in daily activities. The language of instruction is also similar to the language used by teachers in conducting evaluations, for example, describe the process of ..., calculate the ... of ..., and why ... Therefore, most pupils also have no difficulty in understanding science test questions delivered in English. They only have difficulty in expressing the answers in English in a correct and detailed way. Some of them choose to answer in Indonesian to avoid misconceptions.

The results of the questionnaire analysis showed that almost all pupils were able to understand the science concepts conveyed by the teacher in English. However, if pupils were instructed to retell or paraphrase the concepts, they had difficulties, even they incorrectly conveyed the concept. The results of further investigations showed that most pupils made mistakes in understanding the concept of science because the explanation was not sufficiently delivered once in English. These findings were reinforced through interviews with several pupils outside of class hours. The results of pupils' understanding of teachers' instruction, scientific terms, and science concepts are shown in Table 3.

Table 3

Information of pupils' understanding on teachers' instruction, scientific terms, and scientific concepts

\begin{tabular}{llll}
\hline \multirow{2}{*}{ No. } & Observation Aspect & \multicolumn{2}{l}{ Criteria } \\
\cline { 3 - 4 } & & $\begin{array}{l}\text { Do Not Have } \\
\text { Understanding }\end{array}$ & $\begin{array}{l}\text { Have } \\
\text { Understanding }\end{array}$ \\
\hline 1 & Pupils' Understanding of Teachers' Instructions & $18.03 \%$ & $81.97 \%$ \\
\hline 2 & Pupils' Understanding of Scientific Terms & $8.14 \%$ & $91.86 \%$ \\
\hline 3 & Pupils' Understanding of Scientific Concepts & $19.19 \%$ & $80.81 \%$ \\
\hline
\end{tabular}

Based on the results of interviews with teachers, it is revealed that teachers usually repeat the explanation of the science concept to avoid pupils' misconceptions. This indicates that the explanation of the concept in English cannot be done only once. The teacher should also include an explanation in Indonesian in some parts of the concept that are difficult or vulnerable to some misconceptions. Figure 2 shows that the biggest factor that leads pupils to fail of understanding science concepts is insufficient teachers' explanation. 


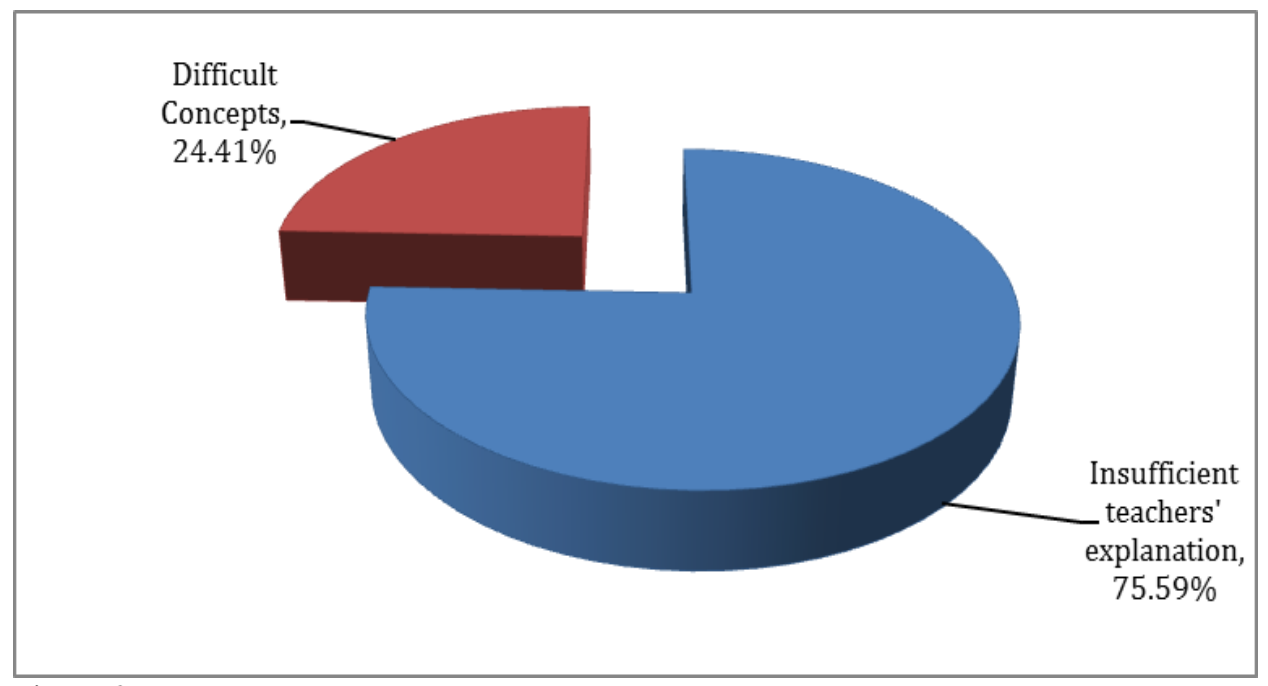

Figure 2

Factors causing pupil mistakes in understanding science concepts

\section{How EMI Should be Applied in Science Class?}

If the answers from the questionnaire and unstructured interviews are analysed and described in a matrix, it can be seen that most pupils (51.86\%) reveal that understanding scientific terms in English is the main key to be able to explain the concept of science correctly. Pupils were classified into six groups as shown in Table 4. The first pupils' group understood teachers' instruction, scientific terms, and science concepts so they did not need teachers to repeat the concepts. They also chose English as the language of assessment. The second pupils' group understood teachers' instruction, scientific terms, and science concepts. They needed teachers to repeat the concepts. They also chose English and Indonesia as the language of assessment. The third pupils' group understood teachers' instruction, scientific terms, and science concepts. They needed teachers to repeat the concepts. But they chose Indonesia as the language of assessment. The fourth pupils' group did not understand teachers' instruction but they understood scientific terms and science concepts. They needed teachers to repeat the concepts. They also chose English and Indonesia as the language of assessment. The fifth pupils' group did not understand the teachers' instruction, scientific terms, and science concepts. They needed teachers to repeat the concepts. They also chose English and Indonesia as the language of assessment. And the sixth pupils' group did not understand the teachers' instruction, scientific terms, and science concepts. They needed teachers to repeat the concepts. They also chose Indonesia as the language of assessment. 
Table 4

Correlation between pupils' understanding of teacher instruction, scientific terms, and science concepts

\begin{tabular}{|c|c|c|c|c|c|c|}
\hline \multirow[b]{2}{*}{ No } & \multicolumn{5}{|l|}{ Aspects } & \multirow[t]{2}{*}{$\%$} \\
\hline & $\begin{array}{l}\text { Understanding } \\
\text { teachers' instruction } \\
\text { using EMI }\end{array}$ & $\begin{array}{l}\text { Understanding } \\
\text { scientific terms }\end{array}$ & $\begin{array}{l}\text { Need an extra } \\
\text { conceptual } \\
\text { explanation }\end{array}$ & $\begin{array}{l}\text { Chosen } \\
\text { language in } \\
\text { assessment }\end{array}$ & $\begin{array}{l}\text { Understanding } \\
\text { science } \\
\text { concepts }\end{array}$ & \\
\hline 1 & $\sqrt{ }$ & $\sqrt{ }$ & - & English & $\sqrt{ }$ & 16.62 \\
\hline 2 & $\sqrt{ }$ & $\sqrt{ }$ & $\sqrt{ }$ & Bilingual & $\sqrt{ }$ & 51.86 \\
\hline 3 & $\sqrt{ }$ & $\sqrt{ }$ & $\sqrt{ }$ & Indonesian & $\sqrt{ }$ & 5.81 \\
\hline 4 & - & $\sqrt{ }$ & $\sqrt{ }$ & Bilingual & $\sqrt{ }$ & 10.72 \\
\hline 5 & - & - & $\sqrt{ }$ & Bilingual & - & 9.39 \\
\hline 6 & - & - & $\sqrt{ }$ & Indonesian & - & 5.60 \\
\hline
\end{tabular}

Table 4 shows a tendency that pupils who understand scientific terms in English are relatively easy to understand the concept of science as a whole. The basic concept of science is relatively difficult to produce pupils who are classified into number 5 . This class of pupils can understand the content of science in English. Meanwhile, pupils who belong to group number 6 certainly face difficulties in understanding English and the basic concepts of science being taught. The results of the interview revealed that pupils in groups numbers 2, 3, and 4 had a high degree of vigilance in working on test questions to minimize errors, pupils felt safer using both Indonesian and monolingual languages. They tend to use pictures in answering questions if they have trouble answering questions in English. The results of this study indicate that EMI can be applied in science teaching with the right formulation using two languages in teaching. More detailed data is shown in Table 4.

\section{What Does Conceptual Test Tell Us?}

Based on the analysis of the conceptual questions used by the teacher, there are two types of questions, i.e. those that require short answers and explanations. Questions that ask for short answers are the type of $\mathrm{Cl}$ questions in the Revised Bloom Taxonomy. The type of question requires pupils to recall knowledge about facts, concepts, principles, and procedures that have been learned by them. Meanwhile, questions that ask for pupils' explanations are types of questions that classify into C2 type in the Revised Bloom Taxonomy. It measures pupils' understanding.

The two types of question groups were classified into two types of data. Both types of data were tested for their normality. The results of data processing with SPSS Vers. 22 indicate that the two types of data are not normal because they have a significant value below 0.05 as shown in Table 5 and Table 6 below.

Table 5

Normality test on explanation answers

\begin{tabular}{lllllll}
\hline & \multicolumn{4}{l}{ Kolmogorov-Smirnov $^{\mathrm{a}}$} & \multicolumn{3}{l}{ Shapiro-Wilk } \\
\cline { 2 - 7 } & Statistic & Df & Sig. & Statistic & Df & Sig. \\
\hline Score_explanation &, 123 & 40 &, 000 &, 745 & 40 &, 000 \\
\hline
\end{tabular}

a. Lilliefors Significance Correction 
Table 6

Normality test on recall answers

\begin{tabular}{lllllll}
\hline & \multicolumn{4}{l}{ Kolmogorov-Smirnov $^{\mathrm{a}}$} & \multicolumn{3}{l}{ Shapiro-Wilk } \\
\cline { 2 - 7 } & Statistic & Df & Sig. & Statistic & Df & Sig. \\
\hline Score_Recall &, 233 & 40 &, 000 &, 850 & 40 &, 000 \\
\hline
\end{tabular}

a. Lilliefors Significance Correction

Because the two types of data were not normally distributed, a non-parametric Wilcoxon Signed Ranks Test was performed as shown in Table 7 and Table 8 below.

Table 7

Wilcoxon signed ranks test

\begin{tabular}{lllll}
\hline & & $\mathrm{N}$ & Mean Rank & Sum of Ranks \\
\hline \multirow{3}{*}{$\begin{array}{l}\text { Score_explanation } \\
\text { Score_recall }\end{array}$} & Negative Ranks & $35^{\mathrm{a}}$ & 22,39 & 783,50 \\
\cline { 2 - 5 } & -Positive Ranks & $5^{\mathrm{b}}$ & 7,30 & 36,50 \\
\cline { 2 - 5 } & Ties & $0^{\mathrm{c}}$ & & \\
\cline { 2 - 4 } & Total & 40 & & \\
\hline
\end{tabular}

a. Score_explanation $<$ Score_recall

b. Score_explanation $>$ Score_recall

c. Score_explanation $=$ Score_recall

Table 8

Test statistics

\begin{tabular}{ll}
\hline$Z$ & Score_explanation - Score_recall \\
\hline$Z$ & $-5,027^{\mathrm{b}}$ \\
\hline Asymp. Sig. (2-tailed) &, 000 \\
\hline a. Wilcoxon Signed Ranks Test & \\
\hline b. Based on positive ranks. &
\end{tabular}

Based on Table 7 and Table 8 , it is found that there is a significant difference between the two test results. The results of the test which required students to recall had a higher average score than the test which required students to explain a science concept. Table 8 shows that the significance value is less than 0.05 , which means that $\mathrm{H}_{0}$ is rejected and $\mathrm{H}_{\mathrm{a}}$ is accepted. This indicates that there is a significant difference between the student's ability to answer questions that require a recall process and questions that ask for an explanation of the science concept.

The low average score on the questions that asked for an explanation was not only caused by the difficulty level of the concept, but also by many factors. The results of unstructured interviews with several students showed that they had doubts about answering questions in English so they only wrote science terms. Because of that, the score is not optimal. Test questions presented in two languages may be a solution for students who do not have good learning habits related to EMI.

\section{DISCUSSION}

The results of data analysis obtained from questionnaires and interviews indicate that EMI can be implemented in science teaching. This can be seen from the high percentage of pupils who can understand teacher's instructions, scientific terms in science, and 
science concepts as shown in Table 3. However, based on the analysis results shown in Table 4, pupils tend to choose teaching strategies and questions assessment presented bilingually. Pupils need to use Indonesian to clarify or ensure the coherence of the science concepts they get from learning. Mastery of scientific terms in the field of science is the key to understand the concept of science as a whole because by understanding this, pupils can look for words, phrases, or sentences that can explain the concept of science as a whole in English. To ensure the sustainability of EMI in science classes, a strong commitment is needed, especially from pupils.

Most pupils are passive English speakers outside the classroom because they do not have good learning habituation as shown in the observation. The main supporting environment for using English is only in the classroom or school. However, almost all pupils think that teaching science with EMI must be continued because it has a positive impact. The conclusion was obtained based on pupils' learning experiences that all the latest information and technology is available in English, even entertainment in the form of computer games is also available in English. In the opinion of all pupils, the skills to read, write, listen, and speak in English help them to understand science material more easily. $90.12 \%$ of pupils agree that the use of EMI in Science class should be continued. This indicates that pupils have a strong commitment to join Science class with EMI. It also indicates that the future use of English as the medium of instruction in science lessons is very potential to be developed.

The use of English as a medium of instruction in science teaching must have specific strategies that are appropriate to Indonesian pupils' characteristics and learning environment. Teaching strategies with English as an inappropriate medium of instruction will make it more difficult for pupils to learn science concepts. This is because teaching material in pupils' mother tongue is much easier to understand than in a foreign language. However, English is used as a medium of instruction to improve pupils' skills in capturing information, using media and technology so that they can compete in the $21^{\text {st }}$ century. Thus, teaching with EMI leads pupils to have information, media, and information and communication literacy. Good language skills, especially English, can support these literacy abilities. In the end, it can support communication skills which is one of the skills that must be possessed by pupils in the $21^{\text {st }}$ century to compete with OECD countries (Chu et al., 2017). Because English is not the first language and even mother tongue for Indonesian pupils, it is natural to find many difficulties. This was also expressed by Briggs et al. (2018) who said that speaking fluently and explaining the material well were challenges faced by teachers who applied EMI in Science class. Learning outcomes that are not optimal as reported by Dearden (2014) and Kirkpatrick (2012) are indicated because of the wrong decision of teaching strategies.

English is more effectively taught in the fourth year in elementary school up to the first year in secondary school than at other levels (Hakuta \& Snow, 1986). This fact is a positive indication that the use of English as a medium of instruction can be implemented with the right strategy. Table 3 shows that $81.97 \%$ of pupils understood the terms of science. This is a good start because usually unfamiliar scientific terms are 
an obstacle to learning with EMI (Hudson, 2009; Owu-Ewie \& Eshun, 2015; Suwarno et al., 2018). Table 3 is also showing $91.86 \%$ of pupils understand instructional learning in English is another positive indicator. The language of instruction is relatively easier because it does not involve the essential concept of discipline but its use is very important because it directs pupils to do an activity.

The results of the investigation in Table 3 show that $80.81 \%$ of pupils understand the essential concepts of science. But the contrasting results are shown that $75.59 \%$ of pupils need a re-explanation. This confirms a large percentage of pupils $(80.81 \%)$ were obtained because the teacher re-explained the concepts. The fact that pupils need a reexplanation is an indication that the first language or mother tongue must still be used as a medium of instruction even with a small proportion. The use of two languages (bilingual instruction) is one of the science learning solutions in which pupils can still understand the latest science and technology in English.

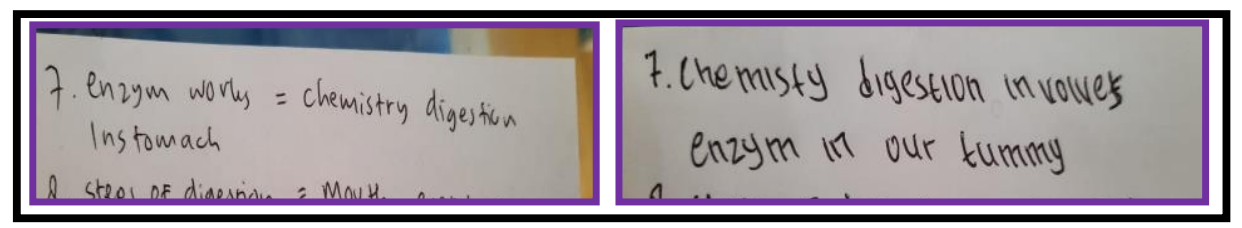

Figure 2

Pupils' answer on science concepts

Figure 2 was obtained from interviews with two eighth grade pupils in Bandung. Both pupils were asked to explain the chemical digestion that occurs in the stomach. There are significant differences in English mastery between the two pupils. After that, the two pupils were asked to write down their understanding of chemical digestion in the stomach as shown in Figure 2 above. The picture on the right shows that the pupil has skills in using English so there are no obstacles in explaining the concept of science. However, the answers of the pupil on the left showed that he was not very proficient in English but he was still able to explain the concepts of science with scientific terms. Further interviews with the pupil revealed that he preferred to use two languages when facing difficulties in translating words, phrases, or a sentence that explains the concept of science. But if it is examined carefully, their verbal explanation can be understood. This finding reinforces the researchers' interpretation that understanding scientific terms is the first step to understand the science concept completely despite using two languages. This finding is also reinforced by the conceptual test results shown in Table 5 and Table 6 that the recall test score is higher than the explanation test score. It is not because of a difficult concept but it is because of constraints in English such as hesitation in using English to answer questions. Pupils are more confident in answering in Indonesian even though they have basic competencies in English communication. The strategy of using two languages may be a solution to stimulate the habit of communicating in English both inside and outside the classroom.

Bilingual class programs can provide many benefits for pupils in various aspects. The limited ability of English is not an obstacle any longer because English mastery is not the sole determinant of pupils' success in understanding material (Bialystok, 2018). 
Huang (2015) also states that using effective strategies to facilitate pupils' understanding with low levels of English will greatly reduce their anxiety and inspire them to be more confident and motivated. Barrett (1994) answered these concerns with the results of his research that English fluency was not an urgent matter in teaching a concept. Therefore, this conceptual teaching strategy with two languages should be designed flexibly so that it can adjust to individual and cultural variations (Creese \& Blackledge, 2010; Hakuta \& Snow, 1986).

Bilingual programs are not only implemented in teaching strategies but also in learning evaluation. Therefore, the evaluation should also be provided in two languages to be able to accurately measure pupils' conceptual knowledge. Wiseman \& Odell (2014) explicitly state that to test a subject taught in English to non-English speakers, the test must be bilingual so there is no doubt whether it only measures language skills or related content. The results of Bialystok (2018) showed that there was no fact that the use of two languages is a barrier to pupils understanding concepts; even standardized test analysis for reading comprehension and mathematics shows that the results of pupils who learn in bilingual classes are better than those in monolingual classes.

The analysis of the interviews with coding techniques involving five teachers shows two main important things. First, teachers who use EMI in science classes must be committed that the main target to be achieved by pupils is mastery of concepts not aspects of language ability merely. This step can ensure that pupils understand the basic concepts of science in depth. Secondly, the teachers revealed that they let pupils only mention words or phrases in English related to the basic concepts of science. This strategy stimulates pupils to encourage speaking English and develop their scientific understanding. Eventually, the communication skills of pupils develop over time. The main key is to understand the terms in science first. The teacher must enrich pupils with those terms. These scientific terms in English act as a "headline" for pupils in understanding the basic concepts of science as a whole. For example, the following are samples of interviews with the same pupil but taken at different times.

\author{
First Interview \\ Teacher : What is the definition of chemical digestion? \\ Pupil : Enzyme works, stomach \\ Second Interview \\ Teacher :Can you tell me the definition of chemical digestion? \\ Pupil : Enzyme works on it. One of the parts is in the stomach
}

Besides, $90.12 \%$ of pupils show positive responses of pupils about the use of English as a medium of instruction in learning science turned out to be incompatible with the fact that pupils rarely use English outside of the classroom. Khasbani (2019) revealed that the low frequency was due to limited exposure to English in the school environment and pupils' residences. Meanwhile, pupils need access to a learning environment that includes mixing languages to develop their understanding of science. Oliveira et al. (2019) also revealed that the use of English in daily life is more effective in increasing concepts of understanding than in the use of textbooks about photosynthesis. These conditions provide space for pupils to discuss so that they have the opportunity to 
express a developed understanding of science concepts and provide opportunities to use the new scientific terms.

Based on the general findings in Table 4, pupils felt insecure when they answered questions in full English. Using bilingual languages is expected not only to keep the coherence concepts but also to grow pupils' confidence. Teachers must formulate and design a special strategy and assessment in this situation as told by Fine \& Furtak (2020). Teachers can also arrange and change the portion of EMI in their class, e.g. 30 $\%$ English and 70\% Indonesian to $50 \%$ English and $50 \%$ Indonesian. Marco-Bujosa et al. (2020) said that the practice of bilingual classes should be flexible in changing languages. When strategies implemented did not help pupils to gain scientific conceptual understandings optimally, teachers can do many steps to increase it. One of them by selecting the understood dictions for pupils as told by Vithanapathirana \& Nettikumara (2020). So pupils can retell concepts in English well.

\section{CONCLUSION}

Pupils in Indonesia understand the scientific term as well as instruction in English. However, they need a re-explanation if they want to understand scientific concepts correctly so that there are no concept errors. This indicates that the explanation of scientific concepts delivered in English is not enough to be given once. This condition does not necessarily hinder the practice of teaching science with EMI. This is because most pupils understand the importance of English as the medium of instruction in teaching science. They assume that this program must be continued. It means that Science learning with EMI can be implemented. To minimize the difficulties in understanding the basic scientific concepts, a bilingual strategy can be implemented by emphasizing the introduction of scientific terms. Based on findings, EMI can be implemented in the Science class by bilingual strategies.

Realizing the difficulties faced by pupils and teachers in learning, the concept of bilingual teaching emerges as a solution. It aims to maintain the coherence of concepts conveyed by the teacher to pupils and avoid pupil misconceptions. Besides, schools that are willing to open learning with EMI (especially for Sciences) should prepare teachers who are proficient in teaching sciences with EMI. Besides, they must also understand the curriculum. Besides, teachers should be flexible in language changing where they can change the language from English to Indonesia if pupils cannot understand the explanation of scientific concepts. Moreover, they should build pupils' confidence in English communication and realize that growing pupils' confidence is a continuous process.

This study portrays problems faced by pupils in understanding scientific concepts delivered by teachers in English in general through a poll on the questionnaire. To obtain detailed information related to the mastery of specific scientific concepts, it would be more representative if a standardized test was used to measure pupils' mastery of scientific concepts. Besides, researches on the implementation of EMI in science classes through bilingual programs will be interesting to study because they contribute to the development of long-term education programs in Indonesia. 


\section{REFERENCES}

Abduh, A., \& Rosmaladewi, R. (2019). Language policy, identity, and bilingual education in Indonesia: A historical overview. XLinguae, 12(1), 219-227. https://doi.org/10.18355/XL.2019.12.01.17

Al Hosni, S. (2014). Speaking difficulties encountered by young EFL learners. International Journal on Studies in English Language and Literature (IJSELL), 2(6), 22-30.

Archila, P. A., \& de Mejía, A.-M. T. (2017). Bilingual university science courses: A questionnaire on professors' practices and espoused beliefs. International Journal of Bilingual Education and Bilingualism. 23(2), 132-152. https://doi.org/10.1080/13670050.2017.1334756

Arkoudis, S. (2003). Teaching English as a second language in science classes: Incommensurate epistemologies? Language and Education, 17(3), 161-173. https://doi.org/10.1080/09500780308666846

Barrett, J. (1994). Why is English still the medium of education in Tanzanian secondary schools? Language, Culture and Curriculum, 7(1), 3-16. https://doi.org/10.1080/07908319409525162

Bax, S. (2010). Researching English bilingual education in Thailand, Indonesia and South Korea. Kuala Lumpur: British Council.

Bialystok, E. (2018). Bilingual education for young children: Review of the effects and consequences. International Journal of Bilingual Education and Bilingualism, 21(6), 666-679. https://doi.org/10.1080/13670050.2016.1203859

Briggs, J. G., Dearden, J., \& Macaro, E. (2018). English medium instruction: Comparing teacher beliefs in secondary and tertiary education. Studies in Second Language Learning and Teaching, 8(3), 673-696. https://doi.org/10.14746/ssllt.2018.8.3.7

Byun, K., Chu, H., Kim, M., Park, I., Kim, S., \& Jung, J. (2011). English-medium teaching in Korean higher education: Policy debates and reality. Higher Education, 62(4), 431-449. https://doi.org/10.1007/s10734-010-9397-4

Chu, S. K. W., Reynolds, R. B., Tavares, N. J., Notari, M., \& Lee, C. W. Y. (2017). 21st Century skills development through inquiry-based learning. Singapore: Springer Singapore, 1007, 978-981. https://doi.Org/10.

Coleman, H. (2010). Teaching and learning in Pakistan: The role of language in education. Islamabad: The British Council, pp 148-157.

Coleman, H. (2016). 'To be consulted, to encourage and to warn': The impact and the limits of language-in-education research in the developing World. In Lawson, R., Sayers, D. (eds). Sociolinguistic Research: Application and Impact. London: Routledge. pp 215-234.

Creese, A., \& Blackledge, A. (2010). Translanguaging in the bilingual classroom: A pedagogy for learning and teaching? The Modern Language Journal, 94(1), 103-115. https://doi.org/10.1111/j.1540-4781.2009.00986.x 
Dearden, J. (2014). English as a medium of instruction-a growing global phenomenon. Oxford: British Council.

Dewi, A. (2017). English as a medium of instruction in Indonesian higher education: A study of lecturers' perceptions. In English medium instruction in Higher Education in Asia-Pacific (pp. 241-258). Springer. DOI: 10.1007/978-3-319-51976-0_13

Drubin, D. G., \& Kellogg, D. R. (2012). English as the universal language of science: Opportunities and challenges. Molecular Biology of The Cell, 23(8), 1399. doi: 10.1091/mbc.E12-02-0108

Fine, C. G. M., \& Furtak, E. M. (2020). A framework for science classroom assessment task design for emergent bilingual learners. Science Education, 104(3), 393-420. https://doi.org/10.1002/sce.21565

Fitriati, S. W. (2015). English bilingual education in an Indonesian public school. In Educational Innovations and Contemporary Technologies (pp. 87-102). London: Palgrave MacMillan. https://doi.org/10.1057/9781137468611_6

Fraenkel, J. R., Wallen, N. E., \& Hyun, H. H. (2011). How to design and evaluate research in education. New York: McGraw-Hill Humanities/Social Sciences/Languages.

Fredriksson, U., Kusanagi, K. N., Gougoulakis, P., Matsuda, Y., \& Kitamura, Y. (2020). A Comparative Study of Curriculums for Education for Sustainable Development (ESD) in Sweden and Japan. Sustainability, 12(3), 1123. https://doi.org/10.3390/su12031123

Hadisantosa, N. (2010). Learning through English: Policies, challenges and prospects: insights from East Asia. Kuala Lumpur: British Council.

Hakuta, K, \& Snow, C. (1986). Summary of Research In Bilingual Education. Stanford: Stanford University. https://www.stanford.edu/search/

He, J.-J., \& Chiang, S.-Y. (2016). Challenges to English-medium instruction (EMI) for international pupils in China: A learners' perspective: English-medium education aims to accommodate international pupils into Chinese universities, but how well is it working? English Today, 32(4), 63-67. DOI: https://doi.org/10.1017/S0266078416000390

Hu, J., \& Gao, X. (2020). Appropriation of resources by bilingual pupils for selfregulated learning of science. International Journal of Bilingual Education and Bilingualism, 23(5), 567-583. https://doi.org/10.1080/13670050.2017.1386615

Huang, D.-F. (2015). Exploring and assessing effectiveness of English medium instruction courses: The pupils' perspectives. Procedia-Social and Behavioral Sciences, 173, 71-78. https://doi.org/10.1016/j.sbspro.2015.02.033

Hudson, P. (2009). Learning to teach science using English as the medium of instruction. Eurasia Journal of Mathematics, Science and Technology Education, 5(2), 165-170. https://doi.org/10.12973/ejmste/75268

Jenkins, J. (2003). World Englishes: A resource book for pupils. New York: Psychology Press.

Kachru, B. B. (1992). The other tongue: English across cultures. Urbana, IL: University of Illinois Press. 
Khasbani, I. (2019). English as a medium of instruction in Indonesian primary and secondary education: Theory and reality. Englisia: Journal of Language, Education, and Humanities, 6(2), 146-161. https://doi.org/10.22373/ej.v6i2.4506

Kirkpatrick, A. (2012). English as an international language in Asia: Implications for language education. In English as an international language in Asia: Implications for language education (pp. 29-44). Dordrecht: Springer. DOI 10.1007/978-94-007-4578-0

Kyeyune, R. (2003). Challenges of using English as a medium of instruction in multilingual contexts: A view from Ugandan classrooms. Language Culture and Curriculum, 16(2), 173-184. https://doi.org/10.1080/07908310308666666

Lamb, M., \& Coleman, H. (2008). Literacy in English and the transformation of self and society in post-Soeharto Indonesia. International Journal of Bilingual Education and Bilingualism, 11(2), 189-205. https://doi.org/doi.org/10.2167/beb493.0

Lauder, A. (2010). The status and function of English in Indonesia: A review of key factors. Hubs-Asia, 10(1), 9-20 https://doi.org/10.7454/mssh.v12i1.128

Lawson, R., \& Sayers, D. (2017). Sociolinguistic research: Application and impact. London: Routledge.

Linneberg, M. S., \& Korsgaard, S. (2019). Coding qualitative data: A synthesis guiding the novice. Qualitative Research Journal, 19(3), 259-270 https://doi.org/10.1108/QRJ12-2018-0012

Marco-Bujosa, L., Levy, A. J., \& McNeill, K. (2020). A Case Study Exploring the Identity of an In-Service Elementary Science Teacher: A Language Teacher First. Research in Science Education, 50(2), 79-98. https://doi.org/10.1007/s11165-017-9681-8

Margana. (2015). Establishing English-Indonesian Bilinguals In Indonesia: From Theory To Practice. RAJAR, 1(10), 365-374. DOI : 10.18535/rajar/v1i10.01

Martin, P. (2003). Bilingual encounters in the classroom. Multilingual Matters, 67-87.

Maxwell-Reid, C. (2020). Classroom discourse in bilingual secondary science: Language as medium or language as dialectic? International Journal of Bilingual Education and Bilingualism, 23(4), 499-512. https://doi.org/10.1080/13670050.2017.1377683

Mukminin, A., Haryanto, E., Sutarno, S., Sari, S. R., Marzulina, L., Hadiyanto, H., \& Habibi, A. (2018). Bilingual education policy and Indonesian pupils' learning strategies. $\begin{array}{llll}\text { Elementary } \quad \text { Education } & \text { 17(3), } & \text { 1204-1223 }\end{array}$ https://doi.org/10.17051/ilkonline.2018.466330

Nassaji, H. (2015). Qualitative and descriptive research: Data type versus data analysis. Sage Publications Sage UK: London, England. https://doi.org/10.1177/1362168815572747

Oliveira, A. W., Weinburgh, M., McBride, E., Bobowski, T., \& Shea, R. (2019). Teaching Science to English Language Learners: Current Research and Practices in the Field of Science Education. The Handbook of TESOL in K-12. Oxford: Wiley Blackwell, pp.277-290. 
Owu-Ewie, C., \& Eshun, E. S. (2015). The Use of English as Medium of Instruction at the Upper Basic Level (Primary Four to Junior High School) in Ghana: From Theory to Practice. Journal of Education and Practice, 6(3), 72-82.

Rini, J. E. (2014). English in Indonesia. Beyond Words, 2/2, 19-39. https://doi.org/10.33508/bw.v2i2.591

Roulston, K. (2010). Reflective interviewing: A guide to theory and practice. Singapore: SAGE Publications Asia-Pacific Pte Ltd

Saeed, A., \& Jarwar, A. Q. (2012). Impact of medium of instruction on achievement Level of Pupils at Higher Secondary Stages in Hyderabad Region of Sindh. Interdisciplinary Journal of Contemporary Research in Business, 4(4), 805-811.

Surdyanto, A. (2018). A Brief View on Bilingual Schools in The Capital of Indonesia. IJEE (Indonesian Journal of English Education), 5(1), 1-15. https://doi.org/10.15408/ijee.v5i1.8018

Suwarno, B., Eka, N., \& Arasuli, A. (2018). English medium instruction class: A case for language policy and planning. Journal of Education and Human Development (JEHD), 7(1), 146-152. https://doi.org/10.15640/jehd.v7n1a17

Taherdoost, H. (2016). Validity and reliability of the research instrument; how to test the validation of a questionnaire/survey in a research. International Journal of Academic Research in Management (IJARM), 5(3), 28-36 https://doi.org/10.2139/ssrn.3205040

Ünsal, Z., Jakobson, B., Molander, B.-O., \& Wickman, P.-O. (2018). Science education in a bilingual class: Problematising a translational practice. Cultural Studies of Science Education, 13(2), 317-340. https://doi.org/10.1007/s11422-016-9747-3

Vithanapathirana, M. V., \& Nettikumara, L. (2020). Improving Secondary Science Instruction through Content and Language Integrated Learning (CLIL) in Sri Lanka. International Online Journal of Education and Teaching (IOJET), 7(1), 141-148.

$\mathrm{Vu}, \mathrm{N}$. T., \& Burns, A. (2014). English as a medium of instruction: Challenges for Vietnamese tertiary lecturers. Journal of Asia TEFL, 11(3), 1-33.

Werther, C., Denver, L., Jensen, C., \& Mees, I. M. (2014). Using English as a medium of instruction at university level in Denmark: The lecturer's perspective. Journal of Multilingual and Multicultural Development, 35(5), 443-462. https://doi.org/10.1080/01434632.2013.868901

Wiseman, A., \& Odell, A. (2014). Should non-English-speaking countries teach in English? | British Council, Retrieved 25 May, 2020 from https://www.britishcouncil.org/voices-magazine/should-non-english-speaking-countriesteach-in-english 